\title{
Formulating Buffered Dissolution Media for Sparingly Soluble Weak Acid and Weak Base Drug Compounds Based on Microenvironmental $\mathrm{pH}_{\mathrm{o}}$ Considerations
}

\author{
Erika S. Stippler ${ }^{1}$, Naiffer E. Romero ${ }^{1}$, and John W. Mauger ${ }^{2, *}$ \\ 'U.S. Pharmacopeial Convention, 12601 Twinbrook Parkway, Rockville, MD 20852 \\ 2University of Utah, College of Pharmacy, Skaggs Pharmacy Institute, Department of Pharmaceutics and Pharmaceutical Chemistry, 30 \\ South 2000 East, Salt Lake City, UT 84112
}

\begin{abstract}
The theoretical framework for dissolution of weak acid and weak base drug compounds in buffered media is well established. Therefore, this article is intended to provide a review of this framework and apply it to formulate buffered dissolution media based on ionic equilibrium conditions within the diffusion layer at the solid-liquid interface. $\mathrm{The}_{\mathrm{pH}}$ in the microenvironment is identified as a singularly important parameter that reflects ionic interactions between dissolving drug and buffer at the solid-liquid interface. This article is focused on (1) formulating buffered dissolution media based on ionic equilibrium conditions at the solid-liquid interface, (2) identifying key physicochemical parameters for both drug and buffer that are relevant to buffer formulation, and (3) providing experimental and calculation-based methods to estimate the $\mathrm{pH}_{\circ}$ at the solid-liquid interface. A shift in emphasis from relying solely on bulk buffer $\mathrm{pH}$ properties forms a basis for formulating buffered dissolution media and also provides insight into the physicochemical factors that affect the dissolution rate of the drug compound.
\end{abstract}

KEYWORDS: Buffered dissolution media; ionic equilibrium; $\mathrm{pH}_{\circ}$ at solid-liquid interface; self-buffering capacity; dissolution.

\section{INTRODUCTION}

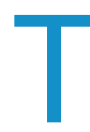

he importance of buffered aqueous media to dissolution testing is evidenced by the number of monographs in the United States Pharmacopeia-National Formulary where conditions for dissolution testing are given (1). Buffer specification is typically in terms of buffer $\mathrm{pH}$, buffer concentration, and chemical composition. These specifications focus on the bulk $\mathrm{pH}$ of the buffered medium and do not explicitly include the influence of the interaction between dissolving drug and buffer at the solid-liquid interface in the microenvironment.

Stippler (2), Rohrs (3), and Levis et al. (4) have emphasized the importance of formulating buffered dissolution media intended for dissolution testing of sparingly soluble weak acid or weak base drug compounds. Buffered aqueous medium affects the dissolution rate of a sparingly soluble weak acid or weak base drug due to ionic interactions between the drug and the buffer species in the microenvironment at the solid-liquid interface (5-14); however, the influence of the buffer can be affected by the self-buffering capacity of the dissolved drug in the microenvironment. The extent to which the buffer influences dissolution rate depends on the ionization constants of the buffer and drug, total molar concentration of the buffer and buffer capacity, concentration of buffer species reacting with the drug compound, total drug solubility, and solubility of the un-ionized form of the drug compound. The $\mathrm{pH}_{\mathrm{o}}$ at the solid-liquid interface

${ }^{*}$ Corresponding author. directly reflects the interaction between dissolved drug and buffer and yields data needed to estimate the relative dissolution rate of the drug. The relative dissolution rate scales the value so that the minimum is 1 under $\mathrm{pH}_{\mathrm{o}}$ conditions where the compound is un-ionized. Relative dissolution rate values $>1$ reflect $\mathrm{pH}_{\circ}$ conditions where solubility increases due to ionization of the compound.

Mass transport models applied to the dissolution of weak electrolytes in aqueous buffered media are well established. Therefore, the purpose of this article is to review and apply the principles from these models to formulate buffered dissolution media for weak acid and weak base drug compounds through an analysis of the interaction between drug and buffer at the solid-liquid interface. Specifically, this article centers around (1) formulating buffered dissolution media based on ionic equilibrium conditions at the solid-liquid interface, (2) identifying key physicochemical parameters for both drug and buffer that are relevant to buffer formulation, and (3) providing experimental and calculation-based methods to estimate the $\mathrm{pH}_{\mathrm{o}}$ at the solid-liquid interface.

\section{Diagrammatic Representation of the Dissolution Process and Ionic Interactions in the Microenvironment}

The dissolution of a weak electrolyte drug at the solidliquid interface can be represented by the model outlined by Higuchi et al. (6). Figure 1 is a representation of steadystate dissolution for a sparingly soluble weak acid drug 


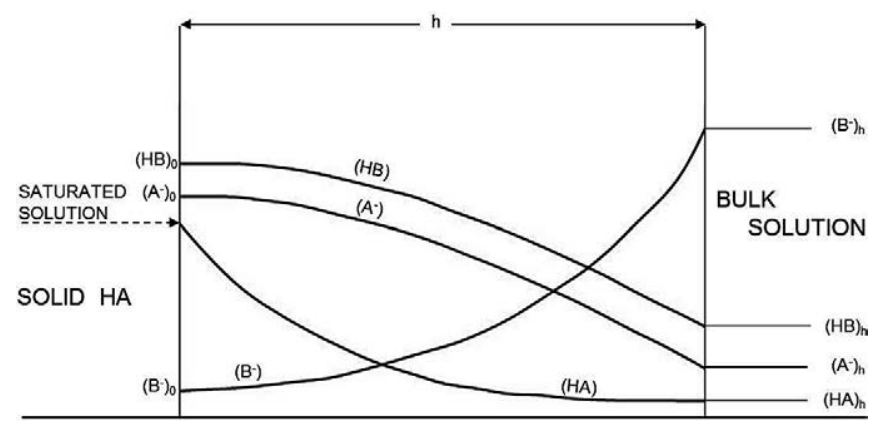

Figure 1. Diagrammatic representation of the dissolution of a weak acid drug compound (HA), into reactive medium containing buffer species $B$. Reprinted from ref 6. Copyright 1958 Wiley-Liss, Inc.

compound in buffered dissolution medium where the drug dissolves at the solid-liquid interface $(x=0)$ and then diffuses through the aqueous diffusion layer into the bulk solution $(x=h)$ ). (Throughout this article, the subscript o refers to the microenvironment at the solid-liquid interface and the subscript $h$ refers to the bulk solution.) The dissolution process at the solid-liquid interface will be affected by the interaction of the proton acceptor buffer species, $\mathrm{B}^{-}$, that is transported from the bulk solution into the diffusion layer where it reacts with the weak acid drug $\mathrm{RCO}_{2} \mathrm{H}$ (shown in the diagram as $\mathrm{HA}$ ) to produce $\mathrm{RCO}_{2}^{-}$(shown in the diagram as $\mathrm{A}^{-}$). The $\mathrm{pH}_{0}$ is a reflection of the ionic equilibrium conditions at the solid-liquid interface and will affect the relative dissolution rate. A similar concentration profile can be constructed to represent the dissolution process for sparingly soluble weak base drug compounds. In the case of a weak base, the incoming reactive buffer species is a proton donor that interacts with $\mathrm{RNH}_{2}$ to form $\mathrm{RNH}_{3}{ }^{+}$. (A primary amine is used for illustrative purposes.)

\section{Equilibrium Conditions at the Solid-Liquid Interface} Case I: Weak Acid Drug Compound, $\mathrm{RCO}_{2} \mathrm{H}$

The ionic reaction that occurs between the weak acid drug compound, $\mathrm{RCO}_{2} \mathrm{H}$, and the proton-accepting buffer species, $\mathrm{B}^{-}$, is given by

$$
\mathrm{RCO}_{2} \mathrm{H}+\mathrm{B}^{-} \leftrightarrow \mathrm{RCO}_{2}^{-}+\mathrm{HB}
$$

The equilibrium expression for this ionic reaction is $(6,8)$

$$
K=K_{\mathrm{a} \text { drug }} / K_{\mathrm{a} \text { buffer }}=\left(\left[\mathrm{RCO}_{2}^{-}\right][\mathrm{HB}]\right) /\left(\left[\mathrm{RCO}_{2} \mathrm{H}\right]\left[\mathrm{B}^{-}\right]\right)
$$

The concentration of the protonated buffer species at the interface, $[\mathrm{HB}]_{\mathrm{o}}$, is the concentration that exists in the bulk plus the amount resulting from the deprotonation of the weak acid immediately after dissolution. Therefore, $[\mathrm{HB}]_{\mathrm{o}}=$ $\left(\mathrm{CHBh}_{\mathrm{HB}}+\left[\mathrm{RCO}_{2}^{-}\right]_{0}\right)$. The concentration of $\left[\mathrm{B}^{-}\right]_{\mathrm{O}}$ in the microenvironment can be defined as $\left[\mathrm{B}^{-}\right]_{0}=\left(\mathrm{C}_{\mathrm{B}^{-}}{ }^{-}-\left[\mathrm{RCO}_{2}^{-}\right]_{0}\right)$. Equation 1 can be rewritten using these definitions as follows:

$K=\left(\left[\mathrm{RCO}_{2}^{-}\right]_{\mathrm{o}}\left(\mathrm{C}_{\mathrm{HBh}}+\left[\mathrm{RCO}_{2}^{-}\right]_{\mathrm{O}}\right)\right) /\left(\left[\mathrm{RCO}_{2} \mathrm{H}\right]_{\mathrm{o}}\left(\mathrm{C}_{\mathrm{Bh}}^{-}-\left[\mathrm{RCO}_{2}^{-}\right]_{\mathrm{O}}\right)\right)$ where $C_{\mathrm{HBh}}$ and $C_{\mathrm{B}}{ }_{\mathrm{h}}$ are the molar concentrations of the un-ionized and ionized buffer components, respectively, in the bulk buffer solution. Equation 2 can be solved for $\left[\mathrm{RCO}_{2}{ }^{-}\right]_{\mathrm{o}}$ by completing the square to give

$$
\left[\mathrm{RCO}_{2}^{-}\right]_{\mathrm{o}}=1 / 2\left(-b+\left(b^{2}-4 a c\right)^{1 / 2}\right)
$$

where $a=1, b=\left(f_{\mathrm{HBh}} C_{\text {Total }}+K\left[\mathrm{RCO}_{2} \mathrm{H}\right]_{\circ}\right)$, and $c=$ - $K\left[\mathrm{RCO}_{2} \mathrm{H}\right]_{\mathrm{O}}\left(f_{\mathrm{B}}{ }_{\mathrm{h}} C_{\text {Total }}\right)$. The quantities $f_{\mathrm{B}}{ }^{-} \mathrm{h}$ and $f_{\mathrm{HBh}}$ are the fractions of $C_{\mathrm{B}} \mathrm{h}$ and $C_{\mathrm{HBh}}$, respectively, in the bulk solution, and $C_{\text {Total }}$ is the total molar buffer concentration where $C_{\text {Total }}=C_{B h}{ }^{-}+C_{H B h}$.

\section{Case II: Weak Base Drug Compound, $\mathrm{RNH}_{2}$}

In the case of a weak base, the ionic reaction that occurs between the weak base drug compound, $\mathrm{RNH}_{2}$, and the proton-donating buffer species, HP, is given by

$$
\mathrm{RNH}_{2}+\mathrm{HP} \leftrightarrow \mathrm{RNH}_{3}^{+}+\mathrm{P}^{-}
$$

The equilibrium expression for this ionic interaction is given by

$$
K=K_{\mathrm{a} \text { buffer }} / K_{\mathrm{a} \text { drug }}=\left(\left[\mathrm{RNH}_{3}{ }^{+}\right]\left[\mathrm{P}^{-}\right]\right) /\left(\left[\mathrm{RNH}_{2}\right][\mathrm{HP}]\right)
$$

The concentration of $\mathrm{P}^{-}$in the microenvironment can be defined as $\left[\mathrm{P}^{-}\right]_{\mathrm{O}}=\left(\mathrm{C}_{\mathrm{Ph}}^{-}+\left[\mathrm{RNH}_{3}{ }^{+}\right]_{0}\right)$, and the concentration of $\mathrm{HP}$ in the microenvironment can be defined as $[\mathrm{HP}]_{0}=$ $\left(\mathrm{CHPh}_{\mathrm{HPh}}-\left[\mathrm{RNH}_{3}{ }^{+}\right]_{\mathrm{o}}\right)$. Equation 4 can be rewritten using these definitions as follows:

$K=\left(\left[\mathrm{RNH}_{3}{ }^{+}\right]_{\mathrm{o}}\left(\mathrm{C}_{\mathrm{Ph}}{ }^{-}+\left[\mathrm{RNH}_{3}{ }^{+}\right]_{\mathrm{o}}\right)\right) /\left(\left[\mathrm{RNH}_{2}\right]_{0}\left(\mathrm{C}_{\mathrm{HPh}}-\left[\mathrm{RNH}_{3}{ }^{+}\right]_{\mathrm{o}}\right)\right)$

where $C_{H P h}$ and $C_{\mathrm{P}^{-}}$h are the molar concentrations of the un-ionized and ionized buffer species, respectively, in the bulk buffer solution. Equation 5 can be solved for $\left[\mathrm{RNH}_{3}{ }^{+}\right]_{0}$ by completing the square to give

$$
\left[\mathrm{RNH}_{3}{ }^{+}\right]_{\circ}=1 / 2\left(-b+\left(b^{2}-4 a c\right)^{1 / 2}\right)
$$

where $a=1, b=\left(f_{\mathrm{P}}{ }_{\mathrm{h}} C_{\text {Total }}+K\left[\mathrm{RNH}_{2}\right]_{\circ}\right)$, and $c=-K\left[\mathrm{RNH}_{2}\right]_{\circ}$ $\left(f_{\mathrm{HPh}} C_{\text {Total }}\right)$. The quantities $f_{\mathrm{P}}{ }^{-}$and $f_{\mathrm{HPh}}$ are the fractions of $C_{\mathrm{Ph}}{ }^{h}$ and $C_{\mathrm{HPh}}$, respectively, in the bulk solution, and $C_{\text {Total }}$ is the total molar buffer concentration where $C_{\text {Total }}=C_{\mathrm{Ph}}{ }^{-}+$ $C_{\text {HPh. }}$

Equations 3 and 6 must be considered approximate since they assume that the diffusion coefficients for all diffusing species are equal. It is advisable to carry out calculations with eqs 3 and 6 using scientific notation and a multiple digit mantissa to avoid the sensitivity of the calculation to round-off error. This analysis shows that concentrations of $\left[\mathrm{RCO}_{2}^{-}\right]_{0}$ and $\left[\mathrm{RNH}_{3}{ }^{+}\right]_{0}$ will increase with

- increasing values of $K$ (i.e., $K_{\mathrm{a} \text { buffer }}<K_{\mathrm{a}}$ drug for a weak acid and $K_{\mathrm{a} \text { drug }}<K_{\mathrm{a} \text { buffer }}$ for a weak base); 
- increasing bulk concentrations of buffer species, $C_{B}{ }^{-}$, for a weak acid and increasing bulk concentrations of buffer species, $C_{\mathrm{HPh}}$, for a weak base; and

- increasing total bulk buffer concentration, $C_{\text {Total, }}$ with a corresponding increase in buffer capacity.

Therefore, buffer $K_{\mathrm{a}}$, buffer composition, total buffer concentration, and buffer capacity can be used as parameters to influence the concentration of ionized species of a weak acid or a weak base drug compound at the solidliquid interface. In turn, the concentration of $\left[\mathrm{RCO}_{2}^{-}\right]_{0}$ or $\left[\mathrm{RNH}_{3}{ }^{+}\right]_{0}$ will influence the total solubility and relative dissolution rate.

\section{Total Solubility and Relative Dissolution Rate for a Weak Acid and a Weak Base Drug Compound}

The dissolution rate of a sparingly soluble weak electrolyte drug is proportional to the total solubility $(6,8)$ where the total solubility, $S_{\text {total, }}$ for a weak acid drug compound, $\mathrm{RCO}_{2} \mathrm{H}$, in the microenvironment is defined by

$S_{\text {total }}=\left[\mathrm{RCO}_{2} \mathrm{H}\right]_{\mathrm{o}}+\left[\mathrm{RCO}_{2}^{-}\right]_{\mathrm{o}}=\left[\mathrm{RCO}_{2} \mathrm{H}\right]_{\mathrm{o}}\left(1+K_{\mathrm{a} \text { drug }} /\left[\mathrm{H}^{+}\right]_{\mathrm{o}}\right)$

where $\left[\mathrm{RCO}_{2} \mathrm{H}\right]_{0}$ is the equilibrium solubility of the un-ionized drug at a specified temperature, $\left[\mathrm{RCO}_{2}^{-}\right]_{0}$ is the molar concentration of the ionized species, and $\left[\mathrm{H}^{+}\right]$ $\circ$ is the hydrogen ion concentration at the solid-liquid interface. Equation 7 predicts that the total solubility will decrease when $\mathrm{pH}_{\mathrm{o}}<\mathrm{p} K_{\mathrm{a}}$ drug and increase when $\mathrm{pH}_{\mathrm{o}}>$ $\mathrm{p} K_{\mathrm{a} \text { drug. }}$

For a weak base drug compound, $\mathrm{RNH}_{2}$, the total solubility in the microenvironment is defined by

$S_{\text {total }}=\left[\mathrm{RNH}_{2}\right]_{\mathrm{o}}+\left[\mathrm{RNH}_{3}{ }^{+}\right]_{\mathrm{o}}=\left[\mathrm{RNH}_{2}\right]_{\mathrm{o}}\left(1+\left[\mathrm{H}^{+}\right]_{\mathrm{o}} / K_{\mathrm{a} \text { drug }}\right)$

where $\left[\mathrm{RNH}_{2}\right]_{0}$ is the equilibrium solubility of the un-ionized weak base at a specified temperature, $\left[\mathrm{RNH}_{3}{ }^{+}\right]_{0}$ is the molar concentration of the ionized species, and $\left[\mathrm{H}^{+}\right]_{0}$ is the hydrogen ion concentration at the solid-liquid interface. Equation 8 predicts that the total solubility will decrease when $\mathrm{pH}_{\mathrm{o}}>\mathrm{p} K_{\mathrm{a} \text { drug }}$ and increase when $\mathrm{pH}_{\mathrm{o}}<\mathrm{p} K_{\mathrm{a}}$ drug.

The relationship between total drug solubility and the dissolution rate for the un-ionized drug species, $R_{\mathrm{u}}$, is given by

$R_{\mathrm{u}}=k\left[\mathrm{RCO}_{2} \mathrm{H}\right]_{\mathrm{o}}$ for a weak acid and $R_{\mathrm{u}}=k\left[\mathrm{RNH}_{2}\right]_{\mathrm{o}}$ for a weak base

When $\mathrm{pH} \approx \mathrm{p} K_{\mathrm{a} \text { drug, }}$, then

$$
\begin{aligned}
& R_{\text {Total }}=k\left(\left[\mathrm{RCO}_{2} \mathrm{H}\right]_{\mathrm{o}}+\left[\mathrm{RCO}_{2}^{-}\right]_{\mathrm{o}}\right) \text { for a weak acid and } \\
& R_{\text {Total }}=k\left(\left[\mathrm{RNH}_{2}\right]_{\mathrm{O}}+\left[\mathrm{RNH}_{3}^{+}\right]_{\mathrm{O}}\right) \text { for a weak base }
\end{aligned}
$$

From eqs 9 and 10, the relative dissolution rate, $R_{\text {rel, }}$ is then defined as
$R_{\text {rel }}=R_{\text {Total }} / R_{\mathrm{u}}=\left(1+K_{\mathrm{a} \text { drug }} /[\mathrm{H}+]_{\mathrm{o}}\right)$ for a weak acid and

$R_{\text {rel }}=R_{\text {Total }} / R_{\mathrm{u}}=\left(1+[\mathrm{H}+]_{\mathrm{o}} / K_{\text {a drug }}\right)$ for a weak base

Equations 9-12 are approximate since they assume that the diffusion coefficients for all diffusing species are equal. Equations 11 and 12 predict that the relative dissolution rate will be approximately 1 when $\mathrm{pH}_{\mathrm{o}}<<\mathrm{p} K_{\mathrm{a} \text { drug, in the }}$

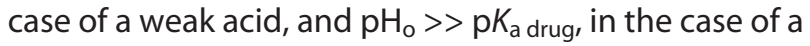
weak base. These equations also predict that the relative dissolution rate will increase when $\mathrm{pH}_{\mathrm{o}}>\mathrm{p} K_{\mathrm{a}}$ drug for $\mathrm{a}$ weak acid and $\mathrm{pH}_{\mathrm{o}}<\mathrm{p} K_{\mathrm{a}}$ drug for a weak base. As emphasized by Ozturk et al. (9), the $\mathrm{pH}_{\mathrm{o}}$ in the microenvironment, not the bulk $\mathrm{pH}_{\mathrm{h}}$, is the parameter that reflects the ionic interactions in the diffusion layer. Therefore, the prediction of the relative dissolution rate based on $\mathrm{pH}_{\text {bulk }}$ may be inaccurate. This shift in emphasis from relying solely on bulk buffer properties forms a basis for formulating buffered dissolution media and provides insight into physicochemical factors that affect the relative dissolution rate of the drug compound, such as self-buffering capacity of sparingly soluble weak electrolyte drugs.

\section{Self-Buffering Capacity of a Weak Acid or Weak Base Drug Compound in the Microenvironment}

As shown in Figure 1, a saturated solution of un-ionized drug, $\mathrm{RCO}_{2} \mathrm{H}$ (shown in the diagram as $\mathrm{HA}$ ), occurs at the solid-liquid interface. The un-ionized species undergoes dissociation to yield $\mathrm{RCO}_{2}^{-}$(shown as $\mathrm{A}^{-}$) and $\mathrm{H}^{+}$. An estimate of $\mathrm{pH}_{\mathrm{o}}$ for a saturated solution of a weak acid in an unbuffered aqueous medium is given by

$$
\mathrm{pH}_{\mathrm{o}}=1 / 2 \mathrm{p} K_{\mathrm{a} \text { drug }}-1 / 2 \log \left[\mathrm{RCO}_{2} \mathrm{H}\right]_{\mathrm{o}}
$$

A similar situation occurs with a weak base drug compound where a saturated solution of un-ionized drug, $\mathrm{RNH}_{2}$, occurs at the solid-liquid interface and dissociates to yield $\mathrm{RNH}_{3}{ }^{+}$and $\mathrm{OH}^{-}$. An estimate of $\mathrm{pH}_{\mathrm{o}}$ for a saturated solution of a weak base drug compound in an unbuffered aqueous medium is given by

$$
\mathrm{pH}_{\mathrm{o}}=1 / 2\left(\mathrm{p} K_{\mathrm{w}}+\mathrm{p} K_{\mathrm{a} \text { drug }}\right)+1 / 2 \log \left[\mathrm{RNH}_{2}\right]_{\mathrm{o}}
$$

Therefore, a weak acid or a weak base is able to contribute to its own $\mathrm{pH}_{\mathrm{o}}$ and self-buffering capacity in the microenvironment. Equations $13 \mathrm{a}$ and $13 \mathrm{~b}$ show that $\mathrm{pH}_{\mathrm{o}}$ is influenced by both $\mathrm{p} K_{\mathrm{a}}$ drug and the solubility of the un-ionized drug. The self-buffering capacity increases with increasing solubility of the un-ionized species of the drug compound (10).

As a consequence of the self-buffering capacity of the drug compound, the relationship between $\mathrm{pH}_{\mathrm{o}}$ and $\mathrm{pH}_{\text {bulk }}$ is an important aspect to consider in formulating a buffered dissolution medium for a weak acid or weak base drug compound. As noted by Mooney et al. (10), $\mathrm{pH}_{\mathrm{o}}$ is expected to equal $\mathrm{pH}_{\text {bulk }}$ only under conditions when the dissociation of the weak acid or weak base drug 
compound is suppressed or when the concentration of the reactive buffer species, a proton acceptor in the case of a weak acid or a proton donor in the case of a weak base, and total buffer concentration is sufficient to swamp the diffusion layer. Therefore, buffer concentration and composition are important parameters in determining the relationship between $\mathrm{pH}_{\mathrm{o}}$ and $\mathrm{pH}_{\text {bulk. }}$. Since $\mathrm{pH}_{\text {bulk }}$ cannot always be expected to equal $\mathrm{pH}_{\mathrm{o}}$ and since $\mathrm{pH}_{\mathrm{o}}$ directly affects the relative dissolution rate (9), methods to estimate $\mathrm{pH}_{\mathrm{o}}$ are needed.

\section{Experimental and Calculation-Based Methods to Estimate $\left[\mathrm{H}^{+}\right]_{0}$ and $\mathbf{p H}_{\mathrm{o}}$ \\ Experimental Methods}

Various experimental methods are available to determine $\mathrm{pH}_{\mathrm{o}}$ for weak electrolyte drugs including measuring the $\mathrm{pH}$ of the supernatant solution from a saturated solution of drug in buffer, $\mathrm{pH}$ indicator dyes in conjunction with diffuse reflectance visible spectroscopy, $\mathrm{pH}$ sensitive spin probes to assess microenvironmental $\mathrm{pH}$, confocal microscopy to image $\mathrm{pH}$ sensitive fluorescent dyes, and micro $\mathrm{pH}$ probes (15). Micro and surface $\mathrm{pH}$ electrodes have also been used to determine $\mathrm{pH}_{\mathrm{o}}$ for drug formulations, such as internally buffered drug formulations of furosemide (16), controlled-release formulations of telmisar$\tan (17)$, and tablet formulations of a poorly soluble weak base, isradipine (18).

\section{Calculation-Based Methods}

The following relationships provide a method to estimate $\left[\mathrm{H}^{+}\right]_{\mathrm{o}}$ and $\mathrm{pH}_{\mathrm{o}}$.

For a weak acid:

$\left[\mathrm{H}^{+}\right]_{\mathrm{O}}=\left(\left[\mathrm{RCO}_{2} \mathrm{H}\right]_{\mathrm{O}} \mathrm{K}_{\mathrm{a} \text { drug }}\right) /\left[\mathrm{RCO}_{2}^{-}\right]_{\mathrm{o}}$ where $\left[\mathrm{RCO}_{2}^{-}\right]_{\mathrm{O}}$ is estimated from eq 3 ;

$$
\mathrm{pH}_{\mathrm{o}}=\mathrm{p} K_{\mathrm{a} \text { drug }}+\log \left(\left[\mathrm{RCO}_{2}^{-}\right]_{\mathrm{o}} /\left[\mathrm{RCO}_{2} \mathrm{H}\right]_{\mathrm{o}}\right)
$$

For a weak base:

$\left[\mathrm{H}^{+}\right]_{0}=\left(\left[\mathrm{RNH}_{3}{ }^{+}\right]_{0} \mathrm{~K}_{\mathrm{a} \text { drug }}\right) /\left[\mathrm{RNH}_{2}\right]_{0}$ where $\left[\mathrm{RNH}_{3}{ }^{+}\right]_{0}$ is estimated from eq 6 ;

$$
\mathrm{pH}_{\mathrm{o}}=\mathrm{p} K_{\mathrm{a} \text { drug }}+\log \left(\left[\mathrm{RNH}_{2}\right]_{\mathrm{o}} /\left[\mathrm{RNH}_{3}{ }^{+}\right]_{\mathrm{o}}\right)
$$

Equation 14 predicts that $\mathrm{pH}_{\mathrm{o}}$ will increase with increasing concentration of $\left[\mathrm{RCO}_{2}^{-}\right]_{0}$ in the case of a weak acid, and eq 15 predicts that $\mathrm{pH}_{\mathrm{o}}$ is will decrease with increasing concentration of $\left[\mathrm{RNH}_{3}{ }^{+}\right]_{0}$ in the case of a weak base. Therefore, $\mathrm{pH}_{\mathrm{o}}$ can be influenced through the parameters that affect the production of either $\left[\mathrm{RCO}_{2}^{-}\right]_{0}$ or $\left[\mathrm{RNH}_{3}{ }^{+}\right]_{0}$, such as the total buffer concentration and the concentration of buffer species $C_{B}{ }^{-}$in the case of a weak acid drug compound or the concentration of buffer species $C_{\mathrm{HPh}}$ in the case of a weak base drug compound.

One situation where equations used to estimate $\mathrm{pH}_{\mathrm{o}}$ would not be expected to provide a quantitative relationship occurs when there is an interaction between drug and buffer ingredients, such as with divalent cations or surfactants. Another situation occurs for a drug formulation where excipients may affect ionic equilibria in the microenvironment.

Experimental and Calculation-Based Values for $\mathbf{p H}_{\mathrm{o}}$ for a Weak Acid Drug Compound, Ibuprofen, and a Weak Base Drug Compound, Bupivacaine

Case I: Weak Acid Drug Compound, Ibuprofen, in a Phosphate Buffer

Experimental $\mathrm{pH}_{\mathrm{o}}$ data in Table 1 were determined from the supernatant of saturated solutions of ibuprofen (ibuprofen USP Spectrum lot 2CHO353) dissolved in USP phosphate buffer systems of known concentration.

\begin{tabular}{|c|c|c|c|c|c|c|c|}
\hline $\begin{array}{l}\text { Total Buffer } \\
\text { Concentration } \\
\text { (phosphate) }\end{array}$ & Initial Buffer pH & $\begin{array}{l}\mathrm{C}_{\mathrm{HPO4}}{ }^{-2} \text { at Initial } \\
\text { Buffer pH }\end{array}$ & $\begin{array}{l}\mathrm{C}_{\mathrm{H}_{2} \mathrm{PO}^{-}} \text {at Initial } \\
\text { Buffer pH }\end{array}$ & $\begin{array}{l}{\left[\mathrm{RCO}_{2}^{-}\right]_{0}} \\
\text { Calculated }^{a}\end{array}$ & Calculated $\mathrm{pH}_{\mathrm{o}}{ }^{b}$ & $\begin{array}{l}\text { Experimental } \\
\mathrm{pH}_{\mathrm{o}}\end{array}$ & $\begin{array}{l}\text { Calculated } \\
\text { Relative } \\
\text { Dissolution } \\
\text { Rate }^{c}\end{array}$ \\
\hline $0.05 \mathrm{M}$ & 6.80 & $2.31 \mathrm{E}-02$ & $2.69 \mathrm{E}-02$ & $1.42 \mathrm{E}-02$ & 6.20 & 6.13 & $37 / 1$ \\
\hline $0.025 \mathrm{M}$ & 6.80 & $1.16 \mathrm{E}-02$ & $1.34 \mathrm{E}-02$ & 8.64E-03 & 5.99 & 5.92 & $23 / 1$ \\
\hline $0.0125 \mathrm{M}$ & 6.80 & $5.78 \mathrm{E}-03$ & $6.72 \mathrm{E}-03$ & 4.91E-03 & 5.74 & 5.69 & $14 / 1$ \\
\hline $0.05 \mathrm{M}$ & 7.20 & $3.42 \mathrm{E}-02$ & $1.58 \mathrm{E}-02$ & 2.17E-02 & 6.39 & 6.36 & $63 / 1$ \\
\hline $0.025 \mathrm{M}$ & 7.20 & $1.71 \mathrm{E}-02$ & 7.90E-03 & $1.30 \mathrm{E}-02$ & 6.16 & 6.15 & $39 / 1$ \\
\hline $0.0125 \mathrm{M}$ & 7.20 & $8.55 \mathrm{E}-03$ & $3.95 \mathrm{E}-03$ & 7.29E-03 & 5.91 & 5.91 & $23 / 1$ \\
\hline $0.05 \mathrm{M}$ & 7.60 & $4.22 \mathrm{E}-02$ & $7.80 \mathrm{E}-03$ & $2.74 \mathrm{E}-02$ & 6.49 & 6.44 & $75 / 1$ \\
\hline $0.025 \mathrm{M}$ & 7.60 & $2.11 \mathrm{E}-02$ & $3.90 \mathrm{E}-03$ & $1.62 \mathrm{E}-02$ & 6.26 & 6.27 & $51 / 1$ \\
\hline 0.0125 & 7.60 & $1.06 \mathrm{E}-02$ & $1.90 \mathrm{E}-03$ & $9.03 \mathrm{E}-03$ & 6.01 & 6.06 & $32 / 1$ \\
\hline \multicolumn{8}{|c|}{$\begin{array}{l}{ }^{a} \text { Calculated using eq } 3 ; K_{a} \text { for phosphate buffer system used to calculate } p_{0} ; p K_{a \text { buffer }}=6.865 \text { (ref 19). Thermodynamic ionization constant data for severa } \\
\text { buffer systems are available in ref } 20 ; p K_{a \text { drug }}=4.57 ;[H A]_{o}=3.3 E-04 M(4) . \\
{ }^{b} \text { Calculated using eq } 14 .\end{array}$} \\
\hline
\end{tabular}

Table 1. Experimental and Calculated Values for $\mathrm{pH}_{\mathrm{o}}$ and Relative Dissolution Rate for a Weak Acid, Ibuprofen 
Table 2. Experimental and Calculated Values for $\mathrm{pH}_{\mathrm{o}}$ and Relative Dissolution Rate for a Weak Base, Bupivacaine ${ }^{a}$

\begin{tabular}{|c|c|c|c|c|c|c|c|}
\hline $\begin{array}{l}\text { Total Buffer } \\
\text { Concentration } \\
\text { (phosphate) }\end{array}$ & Initial Buffer pH & $\begin{array}{l}\mathrm{C}_{\mathrm{HPO} 4^{-2}} \text { at Initial } \\
\text { Buffer pH }\end{array}$ & $\begin{array}{l}\mathrm{C}_{\mathrm{H}_{2 \mathrm{PO} 4}}{ }^{-} \text {at Initial } \\
\text { Buffer pH }\end{array}$ & $\begin{array}{l}{\left[\mathrm{RNH}_{3}{ }^{+}\right]_{0}} \\
\text { Calculated }\end{array}$ & Calculated $\mathrm{pH}_{\mathrm{o}}{ }^{c}$ & $\begin{array}{l}\text { Experimental } \\
\mathrm{pH}_{\mathrm{o}}{ }^{d}\end{array}$ & $\begin{array}{l}\text { Calculated } \\
\text { Relative } \\
\text { Dissolution } \\
\text { Rate }^{d}\end{array}$ \\
\hline $0.1 \mathrm{M}$ & 5 & $1.30 \mathrm{E}-03$ & 9.87E-02 & $2.28 \mathrm{E}-02$ & 6.4 & 6.6 & $45 / 1$ \\
\hline $0.1 \mathrm{M}$ & 7.4 & 7.74E-02 & $2.26 \mathrm{E}-02$ & $1.90 \mathrm{E}-03$ & 7.5 & 7.6 & $5 / 1$ \\
\hline \multicolumn{8}{|c|}{$\begin{array}{l}{ }^{a} \text { Experimental data from ref } 14 . \\
\left.{ }^{b} \text { Calculated using eq } 6 ;\left[R \mathrm{HH}_{2}\right]_{o}=3.07 \mathrm{E}-04 \mathrm{M} \text { at } 37^{\circ} \mathrm{C} \text { estimated from data in ref } 14 ; \mathrm{pK} \text { a drug }=8.24 \text { (ref } 14\right) ; p K_{a} \text { buffer }=6.865(\text { ref } 20) ; \text { calculated using eq } 15 . \\
{ }^{c} \text { Experimental } \mathrm{pH} \mathrm{H}_{0} \text { data from ref } 14 . \\
{ }^{d} \text { Calculated using eq } 12 \text { for a weak base with experimentally determined values for }\left[\mathrm{H}^{+}\right]_{0} \text { from ref } 14 .\end{array}$} \\
\hline
\end{tabular}

Phosphate buffer systems were chosen since the USP specifies this buffer for dissolution testing. The saturated solutions were equilibrated at $37^{\circ} \mathrm{C}$. The value of $K$ for this drug/phosphate buffer system is approximately 197.

The experimental $\mathrm{pH}_{\mathrm{o}}$ values are reasonably consistent with those calculated from eq 14 over a range of total buffer concentrations and initial buffer $\mathrm{pH}$ values. As was noted previously, the calculated values must be considered approximate. Both calculated and experimental values for $\mathrm{pH}_{\mathrm{o}}$ increase with increasing total buffer concentration and increasing concentrations of proton accepting buffer species, $\left[\mathrm{HPO}_{4}{ }^{-2}\right]$. The calculated relative dissolution rates increase with increasing experimental values of $\mathrm{pH}_{\mathrm{o}}$.

Case Il: Weak Base Drug Compound, Bupivacaine, in a Phosphate Buffer

The experimental $\mathrm{pH}_{\mathrm{o}}$ data in Table 2 were determined from saturated solutions of bupivacaine in $0.1 \mathrm{M}$ phosphate buffers equilibrated at $37^{\circ} \mathrm{C}$ (14). The value for $K$ for this drug-phosphate buffer system is approximately 24. The calculated $\mathrm{pH}_{\circ}$ values of 6.4 and 7.5 compare reasonably well with the experimental values of 6.6 and 7.6, respectively. Experimental and calculated values for $\mathrm{pH}_{\mathrm{o}}$ decrease with increasing concentrations of proton donating buffer species, $\left[\mathrm{H}_{2} \mathrm{PO}_{4}^{-}\right]$. The calculated relative dissolution rates increase with decreasing experimental values of $\mathrm{pH}_{0}$.

\section{SUMMARY}

This article has focused on (1) formulating buffered dissolution systems based on the ionic interaction between drug and buffer at the solid-liquid interface, (2) identifying key physicochemical drug and buffer parameters relevant to buffer formulation, and (3) providing experimental and calculation-based methods to estimate $\mathrm{pH}_{\mathrm{o}}$. An analysis of ionic equilibria in the diffusion layer predicts that the generation of ionized drug species is dependent on total buffer concentration and corresponding buffer capacity of the buffer as well as the concentration of either proton-accepting buffer species, $C_{B}{ }^{-}{ }_{h}$, in the case of a weak acid drug compound, or proton-donating buffer species, $\mathrm{C}_{\mathrm{HPh}}$, in the case of a weak base drug compound. The $p K_{a}$ of the buffer is another parameter that influences the production of ionized drug species. An analysis of the self-buffering capacity of the weak electrolyte drug compound indicates that total buffer concentration and buffer capacity are parameters that can be used to influence the relative dissolution rate. The $\mathrm{pH}_{\mathrm{o}}$ at the solid-liquid interface is identified as being singularly important in estimating the relative dissolution rate. Calculation-based methods to determine $\mathrm{pH}_{\circ}$ are potentially useful to estimate the sensitivity of $\mathrm{pH}_{\mathrm{o}}$ to parameters such as total buffer concentration, the concentration of buffer species, and $K_{a}$ buffer. Experimental values for $\mathrm{pH}_{\circ}$ determined under conditions of varying total buffer concentration and varying concentrations of buffer species are useful to confirm the sensitivity of $\mathrm{pH}_{\mathrm{o}}$ to these parameters and to provide data needed to estimate values for the relative dissolution rate. These data can then be used as a screening tool when developing buffered dissolution media that is related to unique physicochemical properties of the drug compound and drug formulation.

\section{REFERENCES}

1. The United States Pharmacopeia and National Formulary USP 37-NF 32; The United States Pharmacopeial Convention, Inc.: Rockville, MD, 2014.

2. Stippler, E. S. Biorelevant Dissolution Test Methods to Assess Bioequivalence of Drug Products. Ph.D. Dissertation, Johann Wolfgang Goethe-Universität, Frankfurt am Main, Germany; Shaker Verlag: Aachen, Germany, 2004; pp 13-15.

3. Rohrs, B. R. Dissolution Method Development for Poorly Soluble Compounds. Dissolution Technol. 2001, $8(3), 6-12$.

4. Levis, K. A.; Lane, M. E.; Corrigan, O. I. Effect of buffer media composition on the solubility and permeability coefficient of ibuprofen. Int. J. Pharm. 2003, 253 (1-2), 49-59. DOI: 10.1016/S0378(02)00645-2.

5. McNamara, D. P.; Amidon, G. L. Reaction Plane Approach for Estimating the Effects of Buffers on the Dissolution Rate of Acidic Drugs. J. Pharm. Sci. 1988, 77 (6), 511-517. DOI: 10.1002/jps.2600770610. 
6. Higuchi, W. I.; Parrott, E. L.; Wurster, D. E.; Higuchi, T. Investigation of Drug Release from Solids II: Theoretical and Experimental Study of the Influence of Bases and Buffers on Rates of Dissolution of Acidic Solids. J. Pharm. Sci. 1958, 47 (5), 376-383. DOI: 10.1002/ jps.3030470522.

7. Hamlin, W. E.; Higuchi, W. I. Dissolution Rate-Solubility Behavior of 3-(Methyl-2-pyrrolidinyl)-indole as a Function of Hydrogen-lon Concentration. J. Pharm. Sci. 1966, 55 (2), 205-207. DOI: 10.1002/jps.2600550216.

8. Higuchi, W. I.; Nelson, E.; Wagner, J. G. Solubility and Dissolution Rates in Reactive Media. J. Pharm. Sci. 1964, 53 (3), 333-336. DOI: 10.1002/ jps.2600530321.

9. Ozturk, S.; Palsson, B. O.; Dressman, J. B. Dissolution of lonizable Drugs in Buffered and Unbuffered Solutions. Pharm. Res. 1988, 5 (5), 272-282. DOI: 10:1023/A:1015970502993.

10. Mooney, K. G.; Mintun, M. A.; Himmelstein, K. J.; Stella, V. J. Dissolution Kinetics of Carboxylic Acids I. Effect of pH under Unbuffered Conditions. J. Pharm. Sci. 1981, 70 (1), 13-22. DOI: 10.1002/jps.2600700103.

11. French, D. L.; Mauger, J.W. Evaluation of the Physicochemical Properties and Dissolution Characteristics of Mesalamine: Relevance to Controlled Intestinal Drug Delivery. Pharm. Res. 1993, 10 (9), 1285-1290. DOI: 10.1023/A:1018909527659.

12. McNamara, D. P.; Amidon, G. L. Dissolution of Acidic and Basic Compounds from the Rotating Disk: Influence of Convective Diffusion and Reaction. J. Pharm. Sci. 1986, 75 (9), 858-868. DOI: 10.1002/ jps.2600750907.
13. Serajuddin, A. T. M.; Jarowski, C. Effect of Diffusion Layer $\mathrm{pH}$ and Solubility on the Dissolution Rate of Pharmaceutical Bases and Their Hydrochloride Salts I: Phenazopyridine. J. Pharm. Sci. 1985, 74 (2), 142-147. DOI: $10.1002 / j p s .2600740208$.

14. Shah, J. C.; Maniar, M. pH-Dependent Solubility and Dissolution of Bupivacaine and Its Relevance to the Formulation of a Controlled Release System. J. Controlled Release 1993, 23 (3), 261-270. DOI: 10.1016/0168/3659(93)90007-R.

15. Badawy, S. I. F.; Hussain, M. A. Microenvironmental pH Modulation in Solid Dosage Forms. J. Pharm. Sci. 2007, 96 (5), 948-959. DOI: 10.1002/jps.20932.

16. Doherty, C.; York, P. Microenvironmental pH control of drug dissolution. Int. J. Pharm. 1989, 50 (3), 223-232. DOI: 10.1016/0378-5173(89)90126-9.

17. Tran, P. H. L.; Tran, H. T. T.; Lee, B.-J. Modulation of Microenvironmental $\mathrm{pH}$ and Crystallinity of lonizable Telmisartan using Alkalizers in Solid Dispersions for Controlled Release. J. Controlled Release 2008, 129 (1), 59-65. DOI: 10.1016/j.conrel.2008.04.001.

18. Tran, T. T.-D.; Tran, P. H.-L.; Choi, H.-G.; Han, H.-K.; Lee, B.-J. The roles of acidifiers in solid dispersions and physical mixtures. Int. J. Pharm. 2010, 384 (1-2), 60-66. DOI: 10.1016/j.jpharm.2009.09.039.

19. Staples, B. R.; Bates, R. G. Two New Standards for the pH Scale. J. Res. Natl. Bur. Stand., Sect. A 1969, 73A (1), 37-41. DOI: 10.6028/jres.073A.004.

20. Goldberg, R. N.; Kishore, N.; Lennen, R. M. Thermodynamic Quantities for the lonization Reactions of Buffers. J. Phys. Chem. Ref. Data 2002, 31 (2), 231-270. DOI: 10.1063/1.1416902. 